\title{
Freeze-Thaw Resistance of Fine-Grained Soils Stabilized with Waste Material Mixtures
}

\author{
Necmi Yarbaşı \\ Department of Civil Engineering \\ Engineering Faculty \\ Ataturk University \\ Erzurum, Turkey
}

\author{
Ekrem Kalkan \\ Department of Civil Engineering \\ Engineering Faculty \\ Ataturk University \\ Erzurum, Turkey
}

\begin{abstract}
This paper evaluates the use of waste material mixtures including marble dust and scrap tire rubber the stabilization of finegrained soils in order to remove the effects of freeze-thaw cycles. In this study, a fine-grained soil material was stabilized by using waste material mixtures. Natural and stabilized fine-grained soil samples were subjected to freeze-thaw cycles under different curing periods. After the freeze-thaw cycles, compressive strength tests were performed to investigate effects of waste material mixtures on the freeze-thaw resistance of fine-grained soil samples. The experimental results showed that the samples of fine-grained soil stabilized with waste material mixtures have high freeze-thaw durability as compared to unstabilized fine-grained soil samples. Consequently, we conclude that waste material mixtures including marble dust and scrap tire rubber, can be successfully used as an additive material to enhance the freeze-thaw durability of fine-grained soils for soil stabilization in the geotechnical applications.
\end{abstract}

Keywords: Fin-grained soil; soil stabilization; freeze-thaw; marble dust; scrap tire rubber

\section{INTRODUCTION}

Fine-grained soil (FGS) is generally classified as expansive soil. This means that some clays will tend to expand as they absorb water and will shrink as water is drawn away. These FGSs contain clay minerals that have the potential for swelling and shrinkage under changing moisture contents. Clay minerals could originate from the weathering of shale, slate, sandstone, and limestone. Another source is the diversification of volcanic ash deposited under marine conditions during geologic times, settled alone or mixed with shale or limestone (Grim 1968; Kalkan and Bayraktutan, 2008). Expansive soils are known to cause severe damage to structures resting on them. However, these soils are very important in geology, construction, and for environmental applications, due to their wide usage as impermeable and containment barriers in landfill areas and other environmentally related applications (Erguler and Ulusay, 2003; Harvey and Murray, 1997; Kayabali, 1997; Keith and Murray 1994; Murray, 2000; Sabtan, 2005). Safe and economic designs of foundations on FGSs and performance of compacted clayey soils for geotechnical purposes require the knowledge of swelling characteristics such as swelling pressure, swelling potential and swelling index. Cyclic drying and wetting phenomena can cause progressive deformation of expansive clayey soils, which may affect building foundations, drainage channels, buffers in radioactive waste disposals, etc. (Guney et al., 2007; Nowamooz and Masrouri, 2008; Rao et al., 2001).

Construction of buildings and other civil engineering structures on weak or soft soil is highly risky because such soil is susceptible to differential settlements due to its poor shear strength and high compressibility. Expansive clays are dominated by clay minerals with the potential for crystalline swelling, such as minerals of the smectite group. These are recognized as having very small particles, even among the clay minerals (Meunier, 2006; Fityus and Buzzi, 2009). Expansive soils are highly plastic that typically contain clay minerals such as montmorillonite that attract and absorb water. If clayey soils contain montmorillonite or a certain type illite, they will have significant swelling potential when wetted and tend to influence their engineering behavior (Shi et al. 2002; Sabtan 2005). Reaction of an expansive soil to changed environmental conditions is to swell or exert large pressures against non-yielding structures; but it may also exhibit a high degree of shrink-swell reversibility with changes in moisture content, leading to deformation and damage to buildings (Popescu 1979; Mohan et al. 1973; Mitchell 1993; Bell and Maud 1995; Du et al. 1999; Abdullah and Al-Abadi, 2010; Kalkan, 2012; Kalkan and Yarbaş1, 2013; Mohamedgread et al., 2019; Yarbaş1 and Kalkan, 2020).

In cold regions, soils in areas with seasonal frost are exposed to at least one freeze-thaw cycle every year. In the freezing period, subsoil moisture moves towards the frozen layer because of a temperature gradient. Void spaces of soil gradually increase due to frost heave and moisture moves to the interstices of the soil and then freezes. In the thawing period, thawing of the frozen layer begins from the top and the bottom at the same time. The maximum soil moisture content appears above frozen layer and becomes temporarilyperched water. Additionally, the soil moisture content under frozen layer is more than it was during the prefrozen period (Zhang and Shijie, 2001; Yarbaş1 et al., 2007).

Nowadays there are various alternatives available to increase the strength and stiffness of the weak soil and to improve the behavior of soil under various loading and environmental conditions (Parihar et al., 2015). Many earth structures such as liners of waste landfills, levees and dams are constructed of FGSs. Also, excavated FGSs might be reused as fill material in some earth structures. In these kinds of applications, there could be a tendency for characteristics of the soils (e.g. strength, volume change and mechanical characteristics) to vary over time. One possible solution to these problems is the use of randomly distributed tensile reinforcement elements in the soil. Such elements are available as polypropylene fibers (Yetimoğlu et al., 2005; Akbulut et al., 2007; Zaimoğlu, 2010; Zaimoğlu and Yetimoğlu, 2012; Yarbaş1 and Kalkan, 2020).

Several stabilization methods are available for stabilizing expansive soils. These methods include stabilization with chemical additives, rewetting, soil replacement, compaction 
control, moisture control, surcharge loading, and thermal methods (Chen, 1988; Nelson and Miller, 1992). All these methods may have the disadvantages of being ineffective and expensive. Therefore, new methods are still being researched to increase the strength properties and to reduce the swell behaviors of expansive soils (Puppala and Musenda, 2002). Many investigators have experienced on natural, fabricated, and by-product materials to use them as stabilizers for the modification of clayey soils (Aitcin et al., 1984; Sandra and Jeffrey, 1992; Kayabali, 1997; Asavasipit et al., 2001; Prabakar et al., 2003; Kalkan and Akbulut, 2004; Cetin et al., 2006; Kalkan, 2006; Akbulut et al., 2007; Kalkan, 2020; Kalkan et al., 2020; Yarbaşı and Kalkan, 2020).

The waste of marble dust (MD) can cause environmental problem and economic loss if the waste is not used. Leaving the waste material to the environment directly can cause environmental problems. Therefore, many countries have still been working on how to reuse the waste material so that they give fewer hazards to the environment. The MD is settled by sedimentation and then dumped away which results in environmental pollution, in addition to forming dust in summer and threatening both agriculture and public health.

Therefore, utilization of the MD in various industrial sectors especially the construction, agriculture, glass and paper industries would help to protect the environment (Karasahin and Terzi, 2007). Wastes can be used to produce new products or can be used as admixtures so that natural sources are used more efficiently and the environment is protected from waste deposits. The MD is generally used as reinforcement material or raw material in various areas and applications (Davini, 2000; Arslan et al., 2005; Acchar et al., 2006; Akbulut and Gurer, 2007; Karasahin ve Terzi, 2007; Saboya et al., 2007; Hwang et al., 2008; Pereira et al., 2008; Aruntas et al., 2010; Celik and Sabah, 2008; Demirel, 2010).

The concept of soil reinforcement with natural fiber materials originated in ancient times. Randomly distributed fiberreinforced soils have recently attracted increasing attention in geotechnical engineering (Yetimoglu and Salbas, 2003). The concept and principle of soil reinforcement was first developed by Vidal (1969). He demonstrated that the introduction of reinforcement elements in a soil mass increases the shear resistance of the medium. The primary purpose of reinforcing soil mass is to improve its stability, increase its bearing capacity, and reduce settlements and lateral deformation. There are several researches investigating the utilizability of scrap tire rubber as low-cost additive material for the soil stabilization (Hausmann, 1990; Prabakar and Sridhar, 2002; Yarbaş1 et al., 2007; Akbulut et al., 2007; Zaimoğlu, 2010; Zaimoğlu and Yetimoğlu, 2012; Kalkan, 2013; Yarbaşı and Kalkan, 2020).

The main objectives of this research are to investigate the utilizability of waste material mixtures including MD and scrap tire rubber (STR) for stabilization of FGSs in geotechnical applications. Also, to test the strength performance of FGSs stabilized with waste material mixtures. To accomplish these objectives, natural FGS samples were stabilized by using different contents of waste material mixtures. The stabilized FGSs obtained by the compaction process were subjected the unconfined compression tests after exposing the freeze-thaw cycles and the results obtained were compared with that of natural FGSs.

\section{EXPERIMENTAL MATERIALS}

\subsection{FGS}

The FGS used in this experimental study was supplied from the clay deposits of Oltu Oligocene sedimentary basin, Erzurum, NE Turkey. This soil with green color and high plasticity is over-consolidated and it has clayey-rock characteristics in natural conditions. It is defined as a high plasticity soil $(\mathrm{CH})$ according to the Unified Soil Classification System (Kalkan, 2003; Kalkan and Akbulut, 2004; Kalkan and Bayraktutan 2008). The chemical composition and engineering properties of the FGS are summarized Tables 1 , and 2, respectively.

Table 1. Chemical properties of FGS and MD

\begin{tabular}{lcc}
\hline Components & FGS & MD \\
\hline $\mathrm{SiO}_{2}$ & 46.83 & 0.36 \\
$\mathrm{Al}_{2} \mathrm{O}_{3}$ & 15.35 & 0.28 \\
$\mathrm{Fe}_{2} \mathrm{O}_{3}$ & 6.81 & 0.04 \\
$\mathrm{CaO}$ & 11.02 & 54.98 \\
$\mathrm{MgO}$ & 4.52 & 0.62 \\
$\mathrm{Na}_{2} \mathrm{O}_{3}$ & 0.92 & 0.03 \\
$\mathrm{~K}_{2} \mathrm{O}$ & 1.23 & 0.07 \\
$\mathrm{TiO}_{2}$ & 0.81 & - \\
$\mathrm{SO}_{3}$ & - & 0.06 \\
$\mathrm{CaO}_{2}$ & - & 43.56 \\
\hline
\end{tabular}

Table 2. Some properties of FGS and MD

\begin{tabular}{lcc}
\hline Properties & FGS & MD \\
\hline Density, $\mathrm{g} \mathrm{cm}^{-3}$ & 2.63 & 2.75 \\
Sand (\%) & 2 & - \\
Silty (\%) & 66 & - \\
Clay (\%) & 32 & - \\
Liquid limit $\left(\mathrm{L}_{\mathrm{L}}, \%\right)$ & 73 & - \\
Plastic limit $\left(\mathrm{P}_{\mathrm{L}}, \%\right)$ & 35 & - \\
Unit volume weight $\left(\mathrm{g} / \mathrm{cm}^{3}\right)$ & 37 & - \\
Porosity $(\%)$ & - & 0.2 \\
\hline
\end{tabular}

\subsection{MD}

The waste MD was obtained in wet form as an industrial byproduct directly from the deposits of marble factories, which forms during the sawing, shaping and polishing processes of marble in Afyon (Turkey) region. The wet marble sludge was dried up prior to the preparation of the samples. The dried material was sieved through a $0.25 \mathrm{~mm}$ sieve to remove the coarse particle (Kalkan and Yarbaş1, 2013). Ths generally used as reinforcement material or raw material in various areas and applications. The chemical composition and physical properties of MD are given in Tables 1 and 2, respectively.

\subsection{STR}

The STR fibers were supplied by local recapping truck tires producer in Erzurum, Northeast Turkey. When the tread on truck tires down, it is more economical to stave off the old tread and replace it than to purchase brand new tires. The tire is shaved off into $150 \mathrm{~mm}$ and smaller strips using a sharp rotating disc. These strips are then ground into scrap rubber (Pierce and Blackwell, 2003; Akbulut et al., 2007). The STR fibers used in this study has length of $1.18 \mathrm{~mm}$. The engineering properties of the STR fiber were given in the Table 3. 


\section{EXPERIMENTAL PROSEDURE}

\subsection{Preparation of sample mixtures}

The FGS used in this study was dried in an oven at approximately $65{ }^{\circ} \mathrm{C}$ and then ground before the preparation of mixtures. The required amounts of FGS, MD and STR were prepared and then blended together under dry conditions. As the waste STR fibers tended to lump together, considerable care and time were spent to get a homogeneous distribution of the waste STR fibers in the mixtures. The weights of the mixtures were determined according to the formula below;

$$
W_{M I X}=W_{F G S}+W_{M D}+W_{S T R}
$$

where $W_{M I X}, W_{F G S}, W_{M D}, W_{S T R}$ are the total dry weights of sample mixtures, FGS, MD and STR, respectively. The component of the samples used in the experimental studies is summarized in Table 4.

Table 3. Some properties of FGS and MD

\begin{tabular}{lc}
\hline Parameters & Value \\
\hline Density $\left(\mathrm{mg} / \mathrm{cm}^{3}\right)$ & $1.153-1.189$ \\
Elastic modulus $(\mathrm{MPa})$ & $1.97-22.96$ \\
Tensile strength $(\mathrm{MPa})$ & 28.1 \\
Extent at failure $(\%)$ & $44-55$ \\
Softening temperature $\left({ }^{\circ} \mathrm{C}\right)$ & 175 \\
\hline
\end{tabular}

Table 4. Some properties of FGS and MD

\begin{tabular}{cccccc}
\hline \multirow{2}{*}{ No } & Sample & \multicolumn{3}{c}{ Materials (\%) } & Total \\
\cline { 3 - 5 } & & CS & MD & STR & $(\%)$ \\
\hline 1 & MIX1 & 100.00 & - & - & 100 \\
2 & MIX2 & 94.5 & 5 & 0.5 & 100 \\
\hline
\end{tabular}

\subsection{Compaction tests}

To prepare the samples for unconfined compression tests, Standard Proctor tests were performed in accordance with ASTM D 698. Each material was evaluated at six different water concentrations in three steps. To ensure uniform compaction, the required quantities of FGS-waste material mixtures were placed inside mold-collars assemblies and compressed alternately in three steps from the two ends until the samples reached the dimensions of the mold.

\subsection{Unconfined compression tests}

The unconfined compressive strength (UCS) values of natural FGS and stabilized FGS samples were determined from the unconfined compressive tests in accordance with ASTMD 2166. This test is widely used as a quick and economical method of obtaining the approximate compressive strength of the cohesive soils. In this study, three cylindrical samples were prepared and tested for each combination of mixtures. The unconfined compressive tests were performed at a deformation rate of $0.16 \mathrm{~mm} / \mathrm{min}$.

\subsection{Freeze-thaw tests}

The freeze-thaw tests were performed by a programmable freezing apparatus. The natural and stabilized FGS samples were subjected to freeze-thaw tests in accordance with ASTM C 666. All samples were placed in the freezing apparatus and conditioned at $-18{ }^{\circ} \mathrm{C}$ for $2.30 \mathrm{~h}$. During the freezing process, the cylindrical samples were insulated by $50 \mathrm{~mm}$ polystyrene to obtain one-dimensional freezing. After the freezing was completed, the samples were transferred from the freezing apparatus into a test room at $+20^{\circ} \mathrm{C}$ for $2.30 \mathrm{~h}$. This freezethaw cycle was repeated 20 times and then these samples were subjected to the unconfined compression tests.

\section{RESULTS AND DISCUSSION}

\subsection{Effect of mixtures on the UCS}

The effect of waste material mixtures on the UCS values of the FGS was obtained by performing the unconfined compression tests under laboratory condition. The natural and waste material mixture-stabilized FGS samples were cured for 1,7 and 28 days and then all samples were subjected to the tests at the end of curing periods. The test results showed that the waste material mixtures improved the UCS values of FGS samples. The increase in the UCS value of stabilized FGS with waste material mixtures was obtained at each different combination (Figure 1). However, the maximum values of the UCS was observed at the stabilized samples with waste material mixtures including 5\% MD and $0.5 \%$ STR wastes. Less and more from optimum content of MD and STR caused the decrease in the UCS values of stabilized FGS.

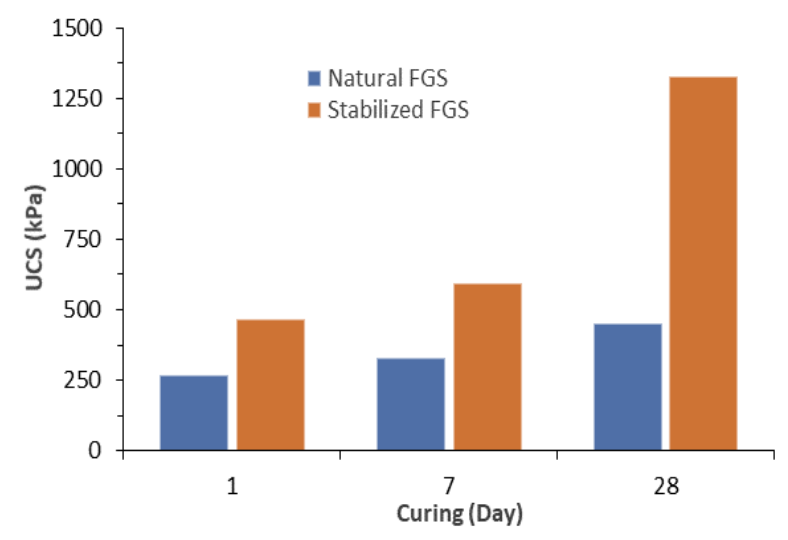

Figure 1. The effects of waste material mixtures on the UCS

The curing time played an important role on the increase of UCS values for stabilized FGS samples when compared that of fresh stabilized FGS samples. It was seen that with the increase in the curing time, UCS values of stabilized FGS samples also increased and maximum UCS values obtained at the 28-day curing time (Fig. 1). The same results were obtained from some experimental studies carried out in the past (Ranjan et. al., 1996; Prabakar and Sridhar, 2002; Akbulut et al., 2007; Zaimoglu, 2010; Hejazi et al., 2012; Kalkan, 2013; Muntohar et al., 2013; Lv and Zhou, 2019; Benziane et al., 2019).

Both the MD and STR contents play an important role in the development of UCS of stabilized FGS. The results indicate that MD-STR mixtures have more effect on the UCS than that of the MD or the STR. The improve in the UCS values of stabilized FGS samples was attributed to the changes in the composition of material mass. The addition of waste material mixtures including MD and STR wastes caused the change in the composition of stabilized FGS. It was noted in literature that the addition of additive changed the composition, mineralogy and particle size distribution of clayey soil (Gillot, 1968; Ola, 1978; Kalkan and Akbulut, 2004).

Similarly, the STR fiber played an important role in the increase in the UCS values of stabilized FGS. The increase in the UCS might be due to the bridge effect of fiber which can efficiently impede the further development of failure planes 
and deformations of the soil (Maher and Ho, 1994; Tang et al., 2007; Zaimoğlu and Yetimoğlu, 2012).

\subsection{Effect of mixtures on the freeze-thaw resistance}

The effects of waste material mixtures on the freeze-thaw resistance of FGS samples were investigated under laboratory conditions. The results obtained from the experimental studies showed that the waste material mixtures including MD and STR wastes increased the UCS values of stabilized FGS. As compared to the unstabilized FGS samples before freeze-thaw cycles, the UCS value of the stabilized FGS sample contents of $5 \% \mathrm{MD}$ and $0.5 \%$ STR wastes and at 28-day curing period was the maximum level. It can also be seen that the stabilized FGS with the MD and STR wastes exhibit more ductile behavior than the unstabilized FGS samples. Similar results were also obtained for granular soils modified with waste additives (Akbulut et al., 2007; Yarbasi et al., 2007; Zaimoğlu, 2010; Kalkan, 2013).

The UCS values of all samples were decreased after freezethaw cycles (Figure 2). It may be attributed to the fact that pore water freezes and forms ice lenses in the pore space between the soil particles; then these ice lenses expand in volume and push particles of the soil and act like springs, increasing gaps among soil particles (Tunç, 2002; Isik et al., 2020). However, the decrease in the UCS values of stabilized FGS samples were lower level than that of unstabilized FGS samples after freeze-thaw cycles (Figure 3). The more UCS values of stabilized samples brought the more freeze-thaw resistance against to the freeze-thaw cycles (Yarbaş1 and Kalkan, 2019).

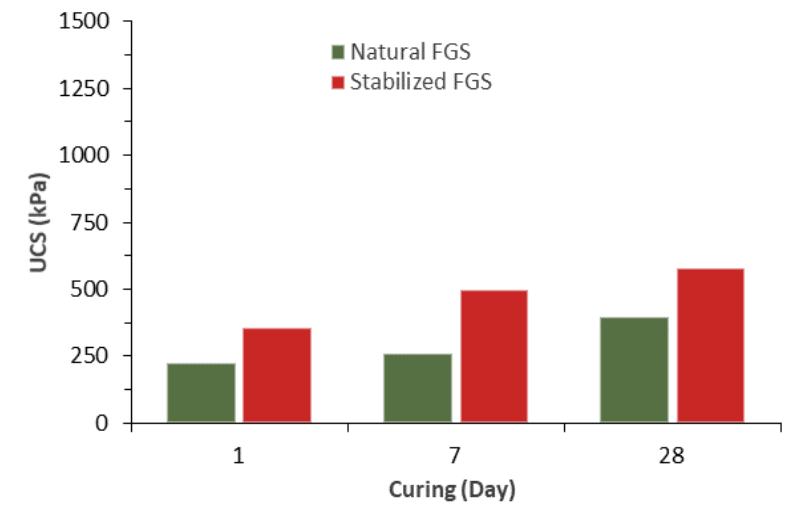

Figure 2. The effects of waste material mixtures on the freezethaw cycles

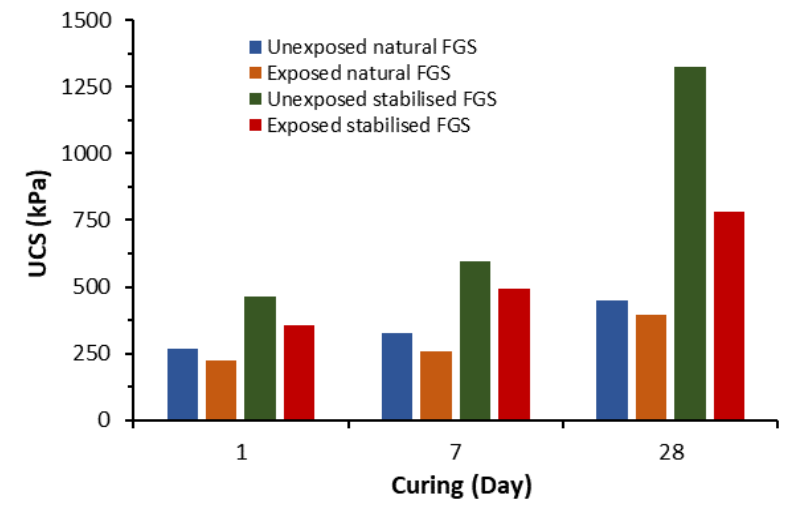

Figure 3. Effects of waste material mixtures on the freezethaw cycles

\section{CONCLUSIONS}

In this study, the effect of waste material mixtures including MD and STR wastes on the strength behavior of stabilized FGS samples was investigated and some conclusions were drawn. It was seen from experimental results that the addition of waste material mixtures increases in the UCS values of stabilized FGS samples. Meanwhile, the stabilized FGS samples were had more freeze-thaw resistance when compared with that of unstabilized FGS samples. It was concluded that waste material mixtures including MD and STR wastes can be used to improve the strength properties of FGS. In addition, this mixture can potentially reduce stabilization costs by utilizing wastes in a cost-effective manner.

\section{ACKNOWLEDGMENTS}

The laboratory portion of this research was carried out in the Soil Mechanics Laboratory of the Geological Engineering Department, Oltu Earth Sciences Faculty, Ataturk University. The author thanks the authorities of the Geological Engineering Department.

\section{REFERENCES}

[1] Abdullah, W.S., Al-Abadi, A.M., 2010. Cationicelectrokinetic improvement of an expansive soil. Applied Clay Science 47, 343-350.

[2] Acchar, W., Vieira, F.A., Hotza, D., 2006. Effect of marble and granite sludge in clay materials. Materials Science and Engineering: A 419, 306.9.

[3] Aitcin, P. C., Ballivy, G., Parizeau, R., 1984. The use of condensed silica fume in grouting. Innovative Cement Grouting. Publication SP-83, ACI Detroit MI, USA, 118 .

[4] Akbulut, S., Arasan, S., Kalkan, E., 2007. Modification of clayey soils using scrap tire rubber and synthetic fibers. Applied Clay Science 38, 23-32.

[5] Akbulut, H., Gurer, C., 2007. Use of aggregates produced from marble quarry waste inasphalt pavements. Build Environ 42, 1921-1930.

[6] Arslan, E.I., Aslan, S., Ipek, U., Altun, S., Yazıcıglu, S., 2005. Physico-chemical treatment of marble processing wastewater and the recycling of its sludge. Waste Management and Research 23, 550-559.

[7] Aruntas, H.Y., Guru, M., Dayi, M., Tekin, I., 2010. Utilization of waste marble dust as an additive in cement production. Materials and Design 31, 4039-4042.

[8] Asavasipit, S., Nanthamontry, W., Polprasert, C., 2001. Influence of condensed silica fume on the properties of cement based solidified wastes. Cement and Concrete Research 31, 1147-1152.

[9] Bell, F.G., Maud, R.R., 1995. Expansive clays and construction, especially of low-rise structures: A viewpoint from Natal, South Africa. Environmental and Engineering Geoscience 1 (1), 41-59.

[10] Benziane, M.M., Della, N., Denine, S., Sert, S., Nouri, S., 2019. Effect of randomly distributed polypropylene fiber reinforcement on the shear behavior of sandy soil. Studia Geotechnica et Mechanica 41 (3) , 1-9.

[11] Celik, M.Y. Sabah, E., 2008. Geological and technical characterization of Iscehisar (Afyon-Turkey) marble 
deposits and the impact of marble waste on environmental pollution. Journal of Environmental Management 87, 106-116.

[12] Cetin, H., Fener, M., Gunaydin, O., 2006. Geotechnical properties of tire-cohesive clayey soil mixtures as a fill material. Engineering Geology 88 (1-2), 110-120.

[13] Chen, F.H., 1988. Foundations on Expansive Soils. Elsevier Scientific Publishing co., Amsterdam.

[14] Davini, P., 2000. Investigation into the desulphurization properties of by-products of the manufacture of white marbles of Northern Tuscany. Fuel 79, 1363-1369.

[15] Demirel, B., 2010. The effect of the using waste marble dust as fine sand on the mechanical properties of the concrete. International Journal of the Physical Sciences 5 (9), 1372-1380.

[16] Du, YL., Li, S.L., Hayashi, S., 1999. Swelling-shrinkage properties and soil improvement of compacted expansive soil, Ning-Liang Highway, China. Engineering Geology, 53, 351-358.

[17] Erguler, Z.A., Ulusay, R., 2003. A simple test and predictive models for assessing swell potential of Ankara (Turkey) Clay. Engineering Geology 67, 331-352.

[18] Fityus, S., Buzzi, O., 2009. The place of expansive clays in the framework of unsaturated soil mechanics. Applied Clay Science 43, 150-155.

[19] Gillot, J.E., 1968. Clay in Engineering Geology. Elsevier, New York.

[20] Grim, R.E., 1968. Clay Mineralogy. McGraw Hill, New York. p 596.

[21] Guney, Y., Sari, D., Cetin, M., Tuncan, M., 2007. Impact of cyclic wetting-drying on swelling behavior of limestabilized soil. Building and Environment 42, 681-688.

[22] Harvey, C.C., Murray, H.H., 1997. Industrial clays in the 21st century: a perspective of exploration, technology and utilization. Applied Clay Science 11, 285-310.

[23] Hausmann, M.R., 1990. Engineering Principles of Ground Modification. McGraw-Hill, New York.

[24] Hejazi, S.H., Sheikhzadeh, M., Abtahi, S.M., Zadhoush, A., 2012. A simple review of soil reinforcement by using natural and synthetic fibers. Construction and Building Materials 30, 100-116.

[25] Hwang, E.H., Ko, Y.S., Jeon, J.K., 2008. Effect of polymer cement modifiers on mechanical and physical properties of polymer-modified mortar using recycled artificial marble waste fine aggregate. Journal of Industrial and Engineering Chemistry 14, 265-271.

[26] Isik, F., Akbulut, K.R., Zaimoglu, A.S., 2020. Influence of Waste Toothbrush Fiber on Strength and FreezingThawing Behavior in High Plasticity Clay. Studia Geotechnica et Mechanica 2020, 1-7.

[27] Kalkan, E., 2003. The improvement of geotechnical properties of Oltu (Erzurum) clayey deposits for using them as barriers. PhD Thesis (in Turkish), Ataturk University, Graduate School of Natural and Applied Science, Erzurum, Turkey.

[28] Kalkan, E., 2006. Utilization of red mud as a stabilization material for preparation of clay liners. Engineering Geology 87 (3-4), 220-229.

[29] Kalkan, E., 2012. Effects of waste material-lime additive mixtures on mechanical properties of granular soils.
Bulletin of Engineering Geology and the Environment 71 (1), 99-103.

[30] Kalkan, E., 2013. Preparation of scrap tires rubber fibersilica fume mixtures for modification of clayey soils. Applied Clay Science 80-81, 117-125.

[31] Kalkan, E., 2020. A Review on the Microbial Induced Carbonate Precipitation (MICP) for Soil Stabilization. International Journal of Earth Sciences Knowledge and Applications 2 (1), 38-47.

[32] Kalkan, E., Akbulut, S., 2004. The positive effects of silica fume on the permeability, swelling pressure and compressive strength of natural clay liners. Engineering Geology 73 (1-2), 145-156.

[33] Kalkan, E., Bayraktutan, M.S., 2008. Geotechnical evaluation of Turkish clay deposits: a case study in Northern Turkey. Environmental Geology 55, 937-950.

[34] Kalkan, E. Yarbaş1, 2013. Use of marble dust waste material for stabilization of compacted clayey soils. Jökull Journal 63, 322-344.

[35] Kalkan, E., Yarbasi, N., Bilici, O., 2019. Strength performance of stabilized clayey soils with quartzite material. International Journal of Earth Sciences Knowledge and Applications 1 (1)1-5.

[36] Kalkan, E., Yarbaşı, N., Bilici, Ö., 2020. The Effects of Quartzite on the Swelling Behaviors of Compacted Clayey Soils. International Journal of Earth Sciences Knowledge and Applications 2 (2), 92-101.

[37] Karasahin, M. Terzi, S., 2007. Evaluation of marble waste dust in the mixture of asphaltic concrete. Construction and Building Materials 21, 616-620.

[38] Kayabali, K., 1997. Engineering aspects of a novel landfill liner material: bentoniteamended natural zeolite. Engineering Geology 46, 105-114.

[39] Keith, K.S., Murray, H.H., 1994. Clay liners and barriers, In: Carr, D.D. (Ed.), Industrial Minerals and Rocks, Sixth Edition. Society for Mining, Metallurgy and Exploration, Littleton, Colorado, pp. 435-452.

[40] Lv, X., Zhou, H., 2019. Shear Characteristics of CementStabilized Sand Reinforced with Waste Polyester Fiber Fabric Blocks. Advances in Materials Science and Engineering 2019, 1-12.

[41] Maher, M.H., Ho, Y.C., 1994. Mechanical-properties of kaolinite fiber soil composite. Journal of Geotechnical Engineering 120 (8),1381-1393.

[42] Meunier, A., 2006. Why are clays minerals small? Clay Minerals 41, 551-566.

[43] Mitchell, J. K., 1993. Fundamentals of soil behavior. 2nd Ed., Wiley, New York.

[44] Mohamedgread, F., Yarbaşi, N., Kalkan, E., 2019. Reinforce in Engineering Properties of Clayey Soils Using Cigarette Butts and Marble Dust. European Journal of Advances in Engineering and Technology 6 (8), 31-37.

[45] Mohan, D., Jain, G.S., Sharma, D., 1973. Foundation practice in expansive soils in India. Proceedings of the 3rd International Conference on Expansive Soils, Haifa, Israel (1973), pp. 125-132.

[46] Muntohar, A.S., Widianti, A., Hartono, E., Diana, W., 2013. Engineering properties of silty soil stabilized with lime and rice husk ash and reinforced with waste plastic 
fiber. Journal Materials Civil Engineering 25, 12601270.

[47] Murray, H.H., 2000. Traditional and new applications for kaolin, smectite, and palygorskite: a general overview. Applied Clay Science 17, 207-221.

[48] Nelson, D.J., Miller, J.D., 1992. Expansive Soils: Problems and Practice in Foundation and Pavement Engineering. John Wiley \& Sons, New York.

[49] Nowamooz, H., Masrouri, F., 2008. Hydromechanical behaviour of an expansive bentonite-silt mixture in cyclic suction-controlled drying and wetting tests. Engineering Geology 101, 154-164.

[50] Ola, S.A., 1978. Geotechnical properties and behaviour of some stabilized Nigerian laterite soils. Quarterly Journal of Engineering Geology 11, 145-160.

[51] Parihar, N.S., Shukla, R.P, Gupta, A.K., 2015. Effect of reinforcement on soil. International Journal of Applied Engineering Research 10 (55), 4147-4151.

[52] Pereira, F.R., Ball, R.J., Rocha, J., Labrincha, J.A., Allen, G.C., 2008. New waste-based clinkers: belite and lime formulations. Cement and Concrete Research 38, 511-521.

[53] Pierce, C.E., Blackwell, M.C., 2003. Potential of scrap tire rubber as lightweight aggregate in flowable fill. Waste Management 23, 197-208.

[54] Popescu, M.E., 1979. Engineering problems associated with expansive clays from Romania. Engineering Geology 14, 43-53.

[55] Prabakar, J., Dendorkar, N., Morchhale, R.K., 2003. Influence of fly ash on strength behavior of typical soils. Construction and Building Materials 18 (4), 263-267.

[56] Prabakar, J., Sridhar, R.S., 2002. Effect of random inclusion of sisal fiber on strength behavior of soil. Construction and Building Materials 16, 123-131.

[57] Puppala, A.J., Musenda, C., 1998. Investigation of geofiber reinforcement method on strength, swell, and shrinkage characteristic of soils. Presented at Fifth International Conference on Composites Engineering, Las Vegas.

[58] Ranjan, G., Vasan, R.M., Charan, H.D., 1996. Probabilistic analysis of randomly distributed fiberreinforced soil. Journals of Geotechnical Engineering Division 122 (6), 419-426.

[59] Rao, S.M., Reddy, B.V.V., Muttharam, M., 2001. The impact of cyclic wetting and drying on the swelling behavior of stabilized expansive soils. Engineering Geology 60, 223-233.

[60] Saboya, F., Xavier, G.C., Alexandre, J., 2007. The use of the powder marble by-product to enhance the properties of brick ceramic. Construction and Building Materials 21, 1950-1960.
[61] Sabtan, A.A., 2005. Geotechnical properties of expensive clay shale in Tabuk, Saudi Arabia. Journal of Asian Earth Science 25, 747-757.

[62] Sandra, T., Jeffrey, C.E., 1992. The effects of filler and admixtures on grout performance. Grouting, Soil Improvement, and Geosynthetics. Geotechnical Engineering Division of ASCE, USA 1, 337-349.

[63] Shi, B., Jiang, H., Liu, Z., Fang, H.Y., 2002. Engineering geological characteristics of expansive soils in China. Engineering Geology 67 (1), 63-71.

[64] Tang, C.S., Shi, B., Gao, W., Chen, F., Cai, Y., 2007. Strength and mechanical behavior of short polypropylene fiber rein-forced and cement stabilized clayey soil. Geotextiles and Geomembranes 25 (3),194-202.

[65] Tunç, A., 2002. Geotechnic and Its Applications on Road Engineering. Atlas Publisher, İstanbul, Turkey (in Turkish).

[66] Vidal, H., 1969. The principle of reinforced earth. Highway Research Record No: 282, 1-16.

[67] Yarbaş1, N., Kalkan, E., 2019. The Stabilization of Sandy Soils by Using the Plastic Bottle Waste. International Journal of Advance Engineering and Research Development 6 (11), 140-144.

[68] Yarbaş1, N., Kalkan, E., 2020. The Mechanical Performance of Clayey Soils Reinforced with Waste PET Fibers. International Journal of Earth Sciences Knowledge and Applications 2 (1) 19-26.

[69] Yarbaş1, N., Kalkan, E., Akbulut, S., 2007. Modification of freezing-thawing properties of granular soils with waste additives. Cold Regions Science and Technology 48, 44-54.

[70] Yetimoglu, T., Inanir, M., Inanir, O.E., 2005. A study on bearing capacity of randomly distributed fiber-reinforced sand fills overlying soft clay. Geotextiles and Geomembranes 23 (2), 174-183.

[71] Yetimoglu, T., Salbas, O., 2003. A study on shear strength of sands reinforced with randomly distributed discrete fibers. Geotextiles and Geomembranes 21, 103 110.

[72] Zaimoğlu, A.S., 2010. Freezing-thawing behavior of fine-grained soils reinforced with polypropylene fibers. Cold Regions Science and Technology 60, 63-65.

[73] Zaimoğlu, A.S., Yetimoğlu, T, 2012. Strength Behavior of Fine-Grained Soil Reinforced with Randomly Distributed Polypropylene Fibers. Geotechnical and Geological Engineering 30, 197-203.

[74] Zhang, D., Shijie, W., 2001. Mechanism of freeze-thaw action in the process of soil salinization in northeast China. Environmental Geology 41, 96-100. 